\section{TWILEY W. BARKER}

Twiley W. Barker, 83, professor emeritus of political science at the University of Illinois at Chicago, died July 13, 2009.

Barker was a founding faculty member of University of Illinois at Chicago's Department of Political Science. He received his Ph.D. from the University of Illinois at Urbana Champaign in 1955. He taught at Southern Illinois University from 19551960, and at the University of Illinois at Urbana-Champaign from 1961-1962. In 1962 he became an associate professor at the predecessor to modern University of Illinois at Chicago when it was housed at Navy Pier. He then taught at the new UIC campus from 1965-1994 where he became known for his knowledge of constitutional law.

At UIC, in addition to his teaching and publishing, he helped shape the political science curriculum, hire faculty, set up a pre-law program, and was undergraduate director for nearly two decades. As a leader in the field of political science, Professor Barker served on the executive council of the American Political Science Association and was a charter member of its committee on the status of African Americans in political science.

Many of Barker's students became leaders in Chicago's civic life, including former U.S. senator and ambassador Carol Moseley Braun; Chicago Park District board president Gery Chico; Cook County commissioner Tony Peraica, Washington, D.C.; lobbyist Tony Podesta; and many famous distinguished attorneys.

"He motivated and inspired students by his example. We were given a chance to live up to his high expectations," Ambassador Moseley Braun said. "I did the best I could to make him proud."

Former White House staff member Tony Podesta said that he learned from Professor Barker the value of "being exact, being prepared, being careful-all things that are important to what I do now."

A native of Louisiana, Barker attended Tuskegee University before joining the Air Force. After military service, he earned a bachelors degree in political science at Southern University in Baton Rouge, and then a doctoral degree at the University of Illinois at Urbana-Champaign.

In 1969, Barker received the national E. Harris Harbison Prize from the Danforth Foundation for "unusual accomplishments in college teaching, but not at the expense of other types of responsibility which the competent teacher-scholar bears." He received the highest teaching award from the university, the first UIC Silver Circle Award for excellence in teaching in 1966.

With his brother Lucius, a Stanford University professor, Twiley Barker coauthored the textbook Civil Liberties and the Constitution: Cases and Commentaries, published by Prentice-Hall in eight editions from 1970 to 1999. The Barkers were joined by coauthors Michael W. Combs (University of Nebraska at Lincoln), H.W. Perry (University of Texas at Austin), and Kevin L. Lyles (UIC) in 1997. Twiley Barker was instrumental in facilitating the ninth edition that is expected to be published this year. It has become the classic civil rights and civil liberties textbook used for nearly four decades at universities throughout the nation.

His later research included a comparative analysis of the first-term performance of Supreme Court justices Thurgood Marshall and Clarence Thomas.

Twiley Barker was a good friend and a good colleague to all faculty and was adored by the thousands of students he taught over the decades.

Notes and other remembrances may be forwarded to the family through the UIC Department of Political Science, Professor Twiley W. Barker Jr. Memorial Fund, 1007 W. Harrison St., M/C 276, Room 1102, Chicago, IL 60607. Former students and political science colleagues may contact the family at twbarker_memorial@att.net.

Dick Simpson, department of political science head, University of Illinois at Chicago Richard Johnson, former department of political science head, University of Illinois at Chicago Kevin Lyles, University of Illinois at Chicago

\section{MICHEL GIRARD}

Michel Girard, professor of political science, Sorbonne, Paris, passed away suddenly on January 27, 2009, after a lengthy battle with cancer. To the end, Professor Girard was an unsurpassed scholar and professional. Ten days before his untimely death, he delivered a superb lecture at Johns Hopkins School of Advanced International Studies (SAIS) in Washington, D.C., on the rise of the new great powers and their integration into the global international system. He had also organized a panel for the International Political Science Association meetings in Santiago, Chile, on which he included two North American scholars.

Professor Girard's interests ranged from Middle East politics to transatlantic relations to international political economy. Recently, he had just coauthored an article on turbulence and stability in transatlantic relations in Political Etrangere with Helen Milner of Princeton University. In his classes at the Sorbonne, he taught a graduate course in international relations theory to a very eclectic group of students from the world over.

But Professor Girard's scholarship did not stop at the water's edge of academia. He applied his ideas to practical politics. At the height of tensions between the United States and France over Iraq policy, he established two ongoing academic exchanges and research symposiums between the Sorbonne and Princeton and the Sorbonne and SAIS. At the very first session of the latter exchange, he placed on the conference agenda precisely the problems that were troubling the two countries.

Professor Girard did not waste his analytic powers either on excessive idealism or on an empty pursuit of realpolitik. He analyzed international politics realistically but with compassion and a desire for shared solutions. His understanding of politics extended to the institutional level, and he always used this perceptiveness in a fair and balanced way in the interest of all of his colleagues.

In the great tradition of French scholarship, Michel Girard reached the minds 
of scholars on the American shore. He was an activist and an institution builder who thought that democratic politics was too important to be left to governments.

Professor Girard will be remembered in the United States in particular for his passionate attention to transatlantic relations. Much like Raymond Aron and JeanBaptiste Duroselle of an earlier era, Michel Girard cared about Europe and North America. Displaying institutional leadership as well as insight, Michel Girard left political science and the world of politics a better place because of his extraordinary initiative and intellectual vision.

Charles Doran Johns Hopkins University, School of Advanced International Studies

\section{LEROY HARDY}

Leroy C. Hardy, emeritus professor of political science at California State University, Long Beach (CSULB), passed away on November 2, 2008, at the age of 81 . He specialized in California government and politics and was best known as a long-term consultant to state legislators on the subject of the reapportionment of legislative districts.

Professor Hardy taught full time in the CSULB Political Science Department from February 1953 until his retirement in 1986; after which he taught on a part-time basis until the early 1990s. He chaired the department from 1980 to 1984 . After leaving the department, he taught in the CSULB Senior University until shortly before his death. Teaching was his first priority, and he was a popular teacher.

Born in Oklahoma and raised in Southern California, Professor Hardy received his BA degree from the University of California, Santa Barbara, in 1949, and his Ph.D. from UCLA in 1955. While still a UCLA graduate student working on the reapportionment of legislative districts, he was appointed in 1951 to the research staff of the Republican-controlled State Reapportionment Committee, and his contribution was so widely admired that he was called upon again in 1961 by the Democratic-controlled California legislature. He participated as well in census-induced redistricting in the early 1970 s and 1980 s, and in the special redistricting forced by the U.S. Supreme Court's decision in the mid-196os mandating one man, one vote.
Professor Hardy's ability to work with both parties on reapportionment issues reflected the integrity and responsibility of his approach to those issues. It also reflected enormous attention to detail, especially in his earliest work before the advent of computers, when reapportionment work was extremely time consuming and laborious. Careers of federal and state legislators depended upon this work.

From his vantage point as a reapportionment expert, Professor Hardy aspired to make reapportionment of legislative districts something other than an exercise favoring political incumbents. At first he believed that government would be more disinterested if a city or community were served by several legislators rather than being incorporated into one district.

Subsequently, following heavily politicized (gerrymandered) redistricting in California in the early 1980s, which he criticized, Professor Hardy helped develop an elaborate bottom-up, community-based, and non-partisan reapportionment concept establishing very small but permanent binding units of redistricting to insulate reapportionment from politics as much as possible. These building-block units, which were implemented in state redistricting in Arizona, were designed to be aggregated into compact legislative districts that would respect county and city boundaries. They were designed to make reapportionment immune from incumbent manipulation, and thereby to make party politics more competitive.

Hardy worked to develop the community-based concept, while serving as a senior research associate at the Rose Institute at Claremont McKenna College, where he collaborated on a series of writings, including Reapportionment Politics (1981), which he edited with Alan Heslop and Stuart Anderson, and Redistricting in the 1980's: A 50-State Survey (1993) with Alan Heslop and George S. Blair. Hardy also wrote two texts for students, California Government (Canfield Press, 4th ed., 1973), and, with Robert Morlan, Politics of California (Dickenson Publishing Co., 1968).

Barry H. Steiner, California State University, Long Beach

\section{WILLIAM V. MOORE}

On April 25, 2009, the College of Charleston and the Charleston community lost a beloved teacher, mentor, scholar, and col- league, William V. Moore, distinguished professor of political science.

In his 37 year career at the college, Dr. Moore was, first and foremost, a truly devoted teacher and mentor. He held many different titles and undertook many responsibilities over the span of his career, but he always identified himself as a teacher. His courses were invariably the first to reach capacity; one of the most persistent tasks for the chair of the department was explaining to students that there simply were no more seats available in Dr. Moore's class. He always had an extremely large number of advisees and took on special responsibilities for student-athletes, always mindful of the special challenges posed by pursuing both athletic and academic achievement.

A caring father and family man, Bill, balanced the life of a teacher with an impressive scholarly output, a passionate commitment to College of Charleston athletics, and a willingness to share his expertise with both print and television journalists in Charleston and across the country. He was as much the voice of the political science department as he was the voice of Cougar basketball.

Bill earned his BA and masters degrees from Southern Illinois University and his Ph.D. from Tulane. He was a well-known expert on South Carolina politics, Southern politics, and political extremism. He was the author of Political Extremism in the United States, co-author of South Carolina Politics and Government, as well as numerous scholarly articles, encyclopedia entries, and publications on Southern and extremist politics, civil rights, electoral politics, campaign spending, and intergovernmental relations. He served as chair of the department of political science, director of the master of public administration program, speaker of the faculty, director of summer programs, director of the Taft Institute for high school civics teachers, NCAA faculty representative, and vice president and president of the Southern Conference. In 1997, Bill was designated as the S.C. Governor's Professor of the Year. He has also been awarded the distinguished teaching award at the college (1981), as well as the distinguished service award (2000), the distinguished advising award (2001), and the first-ever distinguished teacher-scholar award (2001). Bill also served on the Board of Advisors at the Charleston School of Law. 